Article

\title{
Historical Changes of Land Tenure and Land Use Rights in a Local Community: A Case Study in Lao PDR
}

\author{
Saykham Boutthavong ${ }^{1,2, *}$, Kimihiko Hyakumura ${ }^{3}$, Makoto Ehara ${ }^{4}$ and Takahiro Fujiwara ${ }^{5}$ \\ 1 Graduate School of Social and Culture Studies, Kyushu University, 744, Motooka, Nishi-ku, \\ Fukuoka City 819-0395, Japan \\ 2 Faculty of Forestry Sciences, National University of Laos, P.O. Box 7322, Dong Dok Campus, \\ Xaythany District, Vientiane Capital City, Lao PDR \\ 3 Institute of Tropical Agriculture, Kyushu University, 6-10-1 Hakozaki, Higashi-ku, \\ Fukuoka City 812-8581, Japan; hyaku@agr.kyushu-u.ac.jp \\ 4 Center for International Partnerships and Research on Climate Change, Forestry and Forest Products \\ Research Institute (FFPRI), 1 Matsunosato, Tsukuba, Ibaraki 305-8687, Japan; makotoehara1@gmail.com \\ 5 Institute of Decision Science for a Sustainable Society, Kyushu University, 744, Motooka, Nishi-ku, \\ Fukuoka City 819-0395, Japan; takaf217@gmail.com \\ * Correspondence: boutthavong@gmail.com or boutthavong@nuol.edu.la; Tel.: +81-92-642-4219; \\ Fax: $+81-92-642-3077$
}

Academic Editor: Ian Baird

Received: 19 November 2015; Accepted: 18 April 2016; Published: 29 April 2016

\begin{abstract}
Land-titling programs, land and forest allocation programs, and projects on state-allocated land for development and investment in Laos have been key drivers of change in land tenure. These have triggered major shifts in land use rights, from customary, to temporary, and then to permanent land use rights. This article explores how government programs to grant land use rights to individual households have affected the way people have been able to acquire and secure land tenure. For our case study, we selected the village of Napo, the target of many land tenure changes in the past four decades. We collected data from district offices, group discussions with village organizations, and interviews with selected households. The study shows how land use rights shifted over time and reveals that households obtained most of their agricultural land and forestland through a claim process. Original households were mainly land claimers, while migrants were land buyers. The process of formalization and allocation of tenure triggered inequality among households. Attention is needed in future land governance and tenure reforms in order to safeguard the land use rights of local people in an equitable manner.
\end{abstract}

Keywords: land use rights; land tenure; property rights; land acquisition; household land; land formalization; Laos

\section{Introduction}

Significant changes are occurring in Southeast Asia regarding access to and control over land. Demand for land, natural resources, and investment continue to increase, and land use rights are often contested [1]. A formalization of land rights and allocation processes is being implemented through government projects for land titling and registration across Southeast Asia, often supported by the World Bank and the Australian Agency for International Development (AusAID), and they are key instruments in stimulating the land market and leveraging economic development and investment $[2,3]$. In particular, processes aimed at normalizing land access, promoting development, consolidating territorial control, and land ownership [4]. These "land titling models" are based on neoliberal 
principles of individual property rights as the key to economic growth through security of assets, collateral-based investment, and a tax base that depends on property ownership [3].

The formalization of land rights or ownership (referred to here as "land formalization") does not always secure individual ownership rights in an equitable way, and in fact can be detrimental to the customary land rights of local communities. Land formalization is not necessarily an easy process for securing property rights and strengthening livelihoods at all scales and geographic locations [5]. The abilities and capacities of governments to implement land formalization are generally limited [6], and full socio-economic and environmental impact assessments are not implemented in some cases, especially in Laos [7], thus these programs may lead to land grabs by powerful investors [6]. Land formalization directed by governments has not only granted land rights but also resulted in displacing many local people from their customary lands to other lands [8], because poor households are often weak at controlling or managing their properties and at converting their land into capital [6].

In Laos, the main drivers of changes in tenure and land use rights of communities and individual households are (1) the Land Titling Program (LTP) in mainly urban and pre-urban areas, which grants "permanent land use rights" (PLUR) as land titled (bai ta din) to individual households; (2) the Land Use Planning and Land Allocation Program (LUP/LA) or Land and Forest Allocation (LFA) in rural areas across the country, which zones land for communities and grants "temporary land use rights" (TLUR) in the form of a "temporary land use certificate" (TLUC) for agricultural land and forestland for individual households [9-12]; and (3) the allocation of land area for large- and medium-scale investment and development projects, including Special Economic Zones (SEZs), by leasing land for private concessions across the country and for a government resettlement program [13].

These programs do not equally grant and allocate land use rights to individual households, however, and the situation is further complicated by other development and investment projects. The tenure security level granted under the LTP and LFA differs depending on the targets of the project implemented. The security of land ownership granted under TLUR to households in rural areas under the LFA is lower than that granted under PLUR to those in cities under the LTP. Since the land formalization that took place under other ongoing development and investment projects with SEZs is not coordinated between the LTP and LFA [11], investment projects move faster than LTP and LFA implementation [14], so the land use rights allocated by individual projects may conflict with those entitled under the two programs as well as with those granted "customary land use rights" (CLUR) [13]. Moreover, there is not yet any policy consensus on clear tenure arrangement or titling of land and safeguarding of community rights related to development and investment projects [15]. In addition, while the Ministry of Agriculture and Forestry (MAF) plans to continue zoning land under the new LFA scheme, the Ministry of Natural Resources and Environment (MONRE) will subsequently continue what the Ministry of Finance (MOF) has done in the past with respect to the LTP [16].

This article aims to describe the historical changes in the land tenure system in Laos, mainly driven by the LTP and LFA, with a focus on the associated changes in the level of land tenure of individual households in one local community, and then extract policy implications from the findings. More specifically, this paper takes the following approach: (1) we describe historical changes in the ways government programs have granted land use rights to individual households, as well as the policy problems behind these programs by reviewing academic and grey literature; (2) we reveal informal as well as formal ways individual households obtained land use rights triggered by the programs, based on both qualitative and quantitative data obtained in a field survey; and (3) we then argue that a key to future land governance reform involves understanding the historical changes of formal and informal land tenure and land use rights of local communities by especially safeguarding local people's land use rights and reducing the inequity of granting land use rights, in particular for agricultural land and forestland. 


\section{Methods and Study Area}

\subsection{Methods}

For our case study, we carried out a literature review and then conducted a field survey in the selected target village. First, we obtained academic, government policy and grey documents from various sources. The review mainly focused on how changes occurred in land tenure and rights of local communities, including the politics of policy related to the formulation programs, especially in Laos. We searched especially for relevant documents on the LTP and LFA.

Second, based on the review's results, field surveys were conducted in Sangthong District of Vientiane Municipality. We carried out consultation meetings with the head and deputy head of the district offices, and with technical staff in the land and forestry sections of the District Office of Natural Resources and Environment (DONRE) and District Office of Agriculture and Forestry (DAFO), to collect information on both the LTP and LFA, which granted land certificates, and on land tenure. We also carried out group discussions with the head and vice head of the study village, representatives from land and forestry units, youth and women unions, and senior villagers who were most familiar with facts about the village (the study area is described in the following section in more detail). We collected relevant information on historical changes in household land tenure and the ways villagers obtained land for agricultural cultivation. Through our group discussion, we discovered that many households had migrated into the study area.

Third, household interviews were conducted in Napo Village. As the degree of the opportunity for obtaining land area among the households depended on when they settled there, we classified individual households into two groups, depending on whether the household head was born in the village (classified as an "original household") or all members of the households migrated into the village after 1980 ("migrant household"). A total of 47 households were selected randomly, followed by a semi-structured interview with each household. The survey mainly sought information about the households' land tenure and how it had been obtained. The latter we classified as (1) claimed, (2) allocated, (3) inherited, or (4) transferred or bought (see supplement for definition). Our preliminary field survey was conducted in February 2014, and the main survey in March, August, and September 2014.

\subsection{Study Area and Village}

Our study area is in Santhong District, Vientiane Municipality, Laos, located along the Mekong Plain, about 80 kilometers northwest of Vientiane, capital of Laos (Figure 1). Sangthong District is unique for having had several land and forest allocation or tenure programs implemented there that were not introduced in many other districts in Laos. Sangthong is one of the poorest rural districts of Vientiane Municipality, which is located not far from Vientiane. Both local and central governments have provided this district with many socioeconomic development projects, such as public infrastructure improvements and agriculture extensions, including land registration activities.

Based on a preliminary survey in Sangthong District, we selected the village of Napo in village cluster (Koum ban) Five, where many activities had been implemented related to household land use, land and forest allocation, and land title. It is the only village in this cluster that had fully implemented a pilot program for land use planning and land titling carried out by both central and local government organizations, largely due to the fact that it is located not far from the central capital and easier to access than neighboring villages. Moreover, since 1996, large parts of Napo's land area were allocated to the Faculty of Forestry Sciences of the National University of Laos to establish a training model forest for education and research demonstration activities, and several management intervention activities involved many Napo villagers. Moreover, the LFA program was implemented there, as was done in most of the rural villages in Laos, yet it is one of the few villages that saw implementation of the LTP, making it an important village to study in examining the consequences of LTP implementation 
for other rural villages in the future. Therefore, we wanted to see how these interventions had affected the land tenure and land uses of households in Napo.

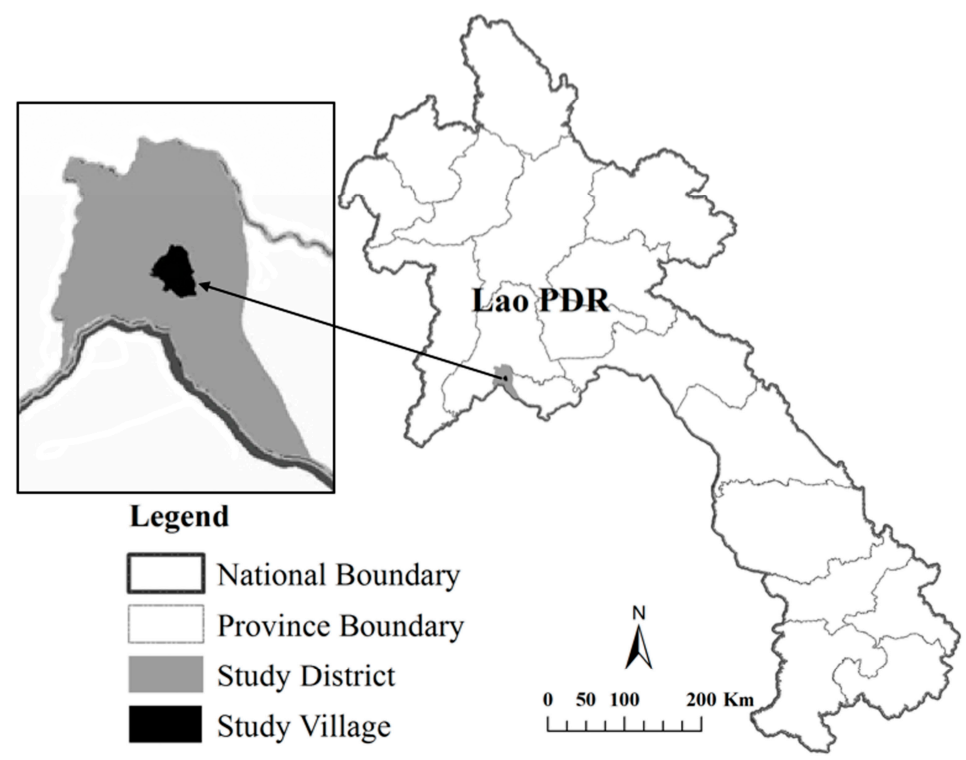

Figure 1. Location map of the case study village. Source: Author's drawing based on GIS database from MONRE and MAF.

The study village is characterized by mainly hilly topography, with an elevation varying between 200 and 400 meters above sea level [17]. The dominant form of vegetation in this area consists of mixed deciduous forest, and the vegetation includes bamboo, degraded forest, and various agricultural uses, including rice paddies, grazing, and upland cultivation.

The main livelihood activities in Napo are agriculture and forestry, such as paddy and upland rice cultivation, cash crops planting, livestock raising, and collecting of bamboo shoots and other non-timber forest products (NTFPs). Some households, especially landless agricultural households and a few with no agricultural land have off-farm occupations such as wage laborers, small shop operators, transportation service operators, district officers with local authorities, and primary and secondary school teachers. The villagers obtain wood to build houses and for firewood from natural forest and fallow land, and bamboo is widely utilized, especially for furniture, thatching, and other products, which are sold on the market.

This village consists of 98 households and 100 families, the majority of which are from the Lao and Khmu ethnic groups, which account for 79 and 21 families, respectively. The total population of the village is about 478 persons, with 239 being female. Road access was first established in 1984, then re-built in 1998/1999, repaired in 2010, and paved in 2013/2014. The village was connected to the electricity grid in 2009.

\section{Results}

\subsection{How the Granting of Land Use Rights Has Changed in Laos}

After the establishment of Lao PDR in 1975, all land was officially nationalized and became managed by the government. Land use area was not distributed or redistributed to individual households, but the state sought to modernize agricultural production for increasing food security $[10,12,18]$. In 1978, a collectivization initiative was introduced, but then halted during the 1980s due to a failure of rice production $[11,18,19]$. In 1986, the government initiated the New Economic Mechanism (NEM) which included multilateral collaboration, economic reforms with price and 
trade liberalization policy and structural reforms [18], and promotion of direct foreign and private investments and a market economy [19-21].

Since the 1990s, several forms of land tenure have been formalized through government programs. These targeted not only state and community lands but also individual lands, including land that had been owned by foreigners before the establishment of Lao PDR, as well as Laotian nationals' land and assets left from the people's revolution in 1975 [18]. The state allocated land use rights based not only on its laws, but also on the customary practices of the local community [11].

\subsubsection{Granting Permanent Land Use Rights through the LTP}

The LTP was introduced in Laos in the mid-1990s. The pilot phase was tested in selected districts in Vientiane Municipality during the years 1995-1997 [18]. LTP1 was implemented during the years 1997-2003 followed by LTP2 during the years 2003-2008 (Figure 2, [9,10,16,18,22]). The LTP was led by the MOF $[11,23,24]$, and currently MONRE is responsible for titling land. The LTP was funded by the Australian government through the World Bank and was aimed at securing the rights of landholders, especially permanent land use rights or private property rights, and implemented for land tax purposes $[2,7,10,23,24]$. Most individual households have now accessed the formal registration system and issuance of land titled as PLUR. In Laos, at present, the highest level of certificate of individual land use rights is "bai ta din" [25], which is a document providing evidence of property rights, and the individual being granted land title is entitled to buy or sell, transfer, and exchange the right to use land including a house; use the land as collateral or a loan guarantee; invest capital into or share in a joint venture; lease (including a house) to another person; convey through inheritance; divide or separate a land parcel; merge or integrate a land parcel; and modify the boundary $[10,12,25,26]$. If the household obtains or accesses land for farming without the title, the household becomes vulnerable to losing that land, including the landholding rights [7]. In fact, poor households still face difficulty in managing and developing their land profitably or even putting it on the market for sale or lease [6].

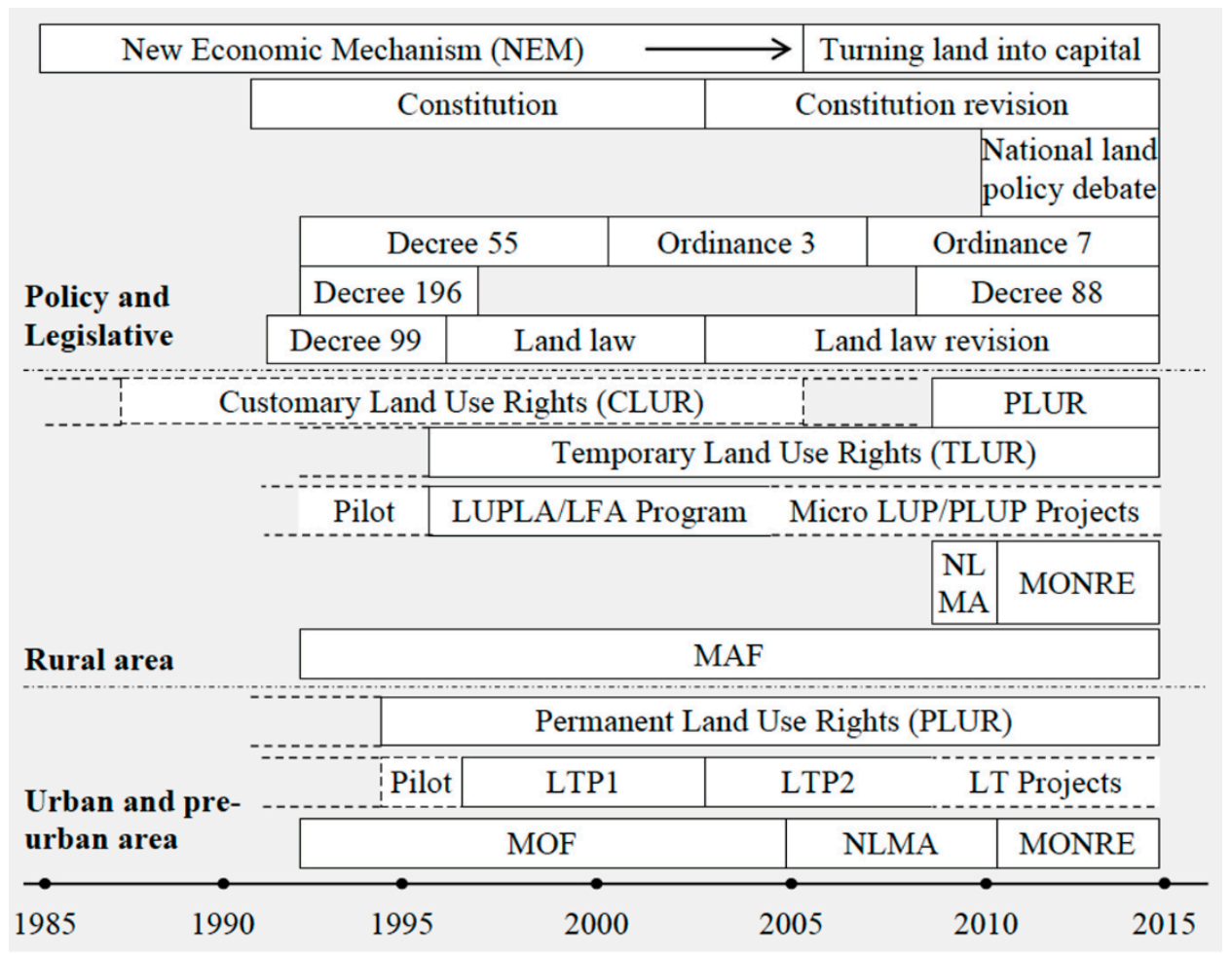

Figure 2. Key events since 1985 relating to the granting of land use rights in Laos. Source: Based on information from $[9,10,16,18,22]$. 
Currently, the extension of land titling in rural areas is proceeding slowly, perhaps due to government budget constraints, institutional changes [7], and the limited capabilities of technical staff, especially at the provincial and district levels [6]. Land registration and titling take longer, and there are difficulties in implementing development and investments projects [27]. According to the five-year target of the 7th National Social Economic Development Plan (7th NSEDP) 2011-2015, the registration and issuance of land titles for one million land parcels should have been completed by 2015 [28], but it is clear that the target will not be achieved [29]. For instance, in the government's fiscal year 2015/16 around 100,000 land parcels should be registered, but only 60,000 parcels will likely be issued land title [30], and then 400,000 parcels are targeted under the 8th NSEDP 2016-2020 [31]. Hence, extension and titling of land in rural areas will still take years.

\subsubsection{Granting Temporary Land Use Rights through the LFA}

The LFA program was introduced in Laos during the 1990s, mainly focusing on rural areas, to protect forests and support the livelihoods of rural farmers and other residents in securing land tenure rights $[11,18,32,33]$. The LFA was one of the main programs to recognize the CLUR of local villagers over resource utilization, with one feature being the granting of legal rights through TLUCs. The CLUR of an individual refers to the protection and use rights of land parcels without any documents certifying land use rights, and that the land parcels have been developed, utilized in a proper manner, long-term, continuously, and regularly. CLUR is recognized by the state by issuing certificates of land through TLUR or PLUR, case by case, with several supporting pieces of evidence [26].

Most rural farmers were granted TLUR to their household [9,12,33]. According to Prime Minister Decree No. 88, Article 3, "the households who acquire land utilization rights will only have the rights to manage, protect, use, usufruct and inherit" [26], and "shall not have the right to transfer or use the land certificate as share contribution, or to use it as security or to lease" [25]. The LFA program was led by the MAF (Figure 2), and most activities were conducted by local authorities such as the Provincial Agriculture and Forestry Office (PAFO), DAFO, and/or district land allocation committees.

Literature reviewed for this study identified several challenges faced by the LFA, however. First, since the local authorities have limited human resources, time, and technical support $[9,33-35]$ the results were low in quality. For example, most of the information on land that was registered has gone missing; the LFA was incomplete in some villages; and there was a lack of local community involvement in the process [36]. The LFA just defined the boundaries of the village and the individual households, with no follow-up activities after LFA completion $[9,35,37]$.

Second, LFA implementation may exaggerate inequality of local residents in land tenure. For instance, households that had been in the community longer were able to obtain better land and tended to be granted a larger area than the newer households, who had newly settled in the community and generally had a lack of capital and labor forces [32]. Furthermore, the zoned boundaries forced poor rural households to follow the new delineations, which limited villagers' ability to utilize resources beyond the village boundary [8] and restricted the numbers of land parcels and the size of land, especially in upland areas [38]. Local villagers say that they have seen no advantages from the changes in tenure and no improvements in their livelihoods, and this is especially so for the poorest farmers [39].

Third, the LFA could cause threats to the traditional land use system. For instance, the number of land use categories increased, the rotation period in the uplands was reduced, and some households lost some of their fallow land [39]. Since the migrant households that moved in after completion of the LFA lacked opportunities to access land and resources [11], they claimed more land area, especially fallow and community land [34]. Informal or illegal transfers of TLUR occurred in many parts of the country $[12,33]$. 
Moreover, a new LFA scheme called "participatory land use planning" (PLUP) was initiated in 2009. Under this approach, pilot projects were carried out in the provinces of Huaphanh and Laung Prabang under the programs "Reducing Emissions from Deforestation and Forest Degradation" (REDD+), the "Participatory Land and Forest Management Project for Reducing Deforestation in Lao PDR" (PAREDD), and "Climate Protection through Avoided Deforestation" (CliPAD). The projects' intention was to register and title both individual households and communal land [16], but there are still uncertainties when putting PLUP into practice, and the long-term outcomes of safeguarding tenure rights of the affected local communities are not known at present [37].

\subsubsection{Land Transformation and the Politics of Policy}

From a politics of policy perspective, natural resources management including a land formulation program can be politically challenging. Since 1975, Lao PDR has been governed by one-party system, with the Lao People's Revolutionary Party (LPRP) controlling the entire country. All ministries and organizations in the central government and local authorities are under the influence of the LPRP hierarchy, and national social and economic development policies have followed the party congress's directives. The LPRP is the highest organization leading the country toward a socialist market-based economy, including natural resources management policies and land and forest resources transformation in particular $[18,40]$. All policies for formalization of land rights and ownership are also guided by the party $[18,40]$.

Even though the country is ruled under a single party system, several different government sectors have been influenced in natural resources management policies. Many ministries are involved in and have responsibilities to manage land, including MONRE, MAF, Ministry of Energy and Mines, Ministry of Public Work and Transport, Ministry of Industry and Commerce, Ministry of National Defense. In most cases, policies linked to natural resources management are approved by the central level of government, and the local authorities are required to follow the directives of the central government [21]. They are interested not only in managing land for local communities and individual households, but also in reserving land for investment, concessions and development projects, and security purposes [40]: for instance, reserving land for hydropower dams, economic development zones, concession and public development projects to boost national economic growth, and poverty alleviation [41]. In some cases, the Military is interested in natural resources, especially mineral and forest resources, and it operates development projects $[18,40]$. In some cases, the intention of the Military is not only serving national interests, but also carrying out activities in parallel with social and economic development, such as mining and logging [42]. Moreover, several investors from neighboring countries, such as Vietnam and China, are also interested in natural resources of Laos, especially land and forests [43]. The granting of land concessions to foreign companies is influenced by political relationships, especially between Laos and the investor's governments [44-46].

In addition, decision-making processes are likely to be less transparent and to be managed by ministries and organizations in the central government [40]. For example, there have been cases of large-scale land allocations being approved by the central government and processed for concessions without adequate land surveys, [46] no clear management plan of the projects, and sometimes a company has paid a bribe to obtain signatures in the process for approval. Therefore, in several cases, land-related issues have occurred at multiple levels, such as overlapping management intervention areas between actors, resulting in conflicts and threats affecting local farmers' livelihood activities $[40,47,48]$. 
Two other policies, LTP1 and LTP2, which were supported by the World Bank and AusAID, focused on areas where land conflicts were relatively uncommon [40], and lacked supporting land policy development. Donors required the LTPs to conduct social economic and environmental impact assessments but the government did not implement them [7], therefore the concepts of donor support of the LTP may not be in line with the government's interests. Thus, conflicting interests between the government and donors could hamper further collaboration programs.

\subsection{How Changes Occurred in the Case Study Village}

\subsubsection{The History of Household Settlement in the Study Village}

According to group discussions with village organizations, villagers had started to use this area for paddy field expansion in the 1890s. In 1952, there were around 20 households in the village, but it was broken up in the 1960s due to the Indochina War conflict. In 1967, seven households re-settled in the same place. There were 14 and 20 households in 1969 and 1973, respectively. During the years 1980-1983, around 10 households from Xiengkhouang Province settled in the village, while some migrant households moved out in 1981. During 1989 and 1990, about 40 households migrated from Vientiane Province, while some households migrated out. In 1996, there were 45 households, with 36 being Lao and $9 \mathrm{Khmu}$ [17].

Figure 3 shows how the sample households settled in the study village. Before 1980, many original households returned and re-settled here, and there were no new migrant households. Many villagers born there married, became independent from their parents, and built new houses. Migrant households moved to this village after 1980, with most having arrived during the years 1994-1999.

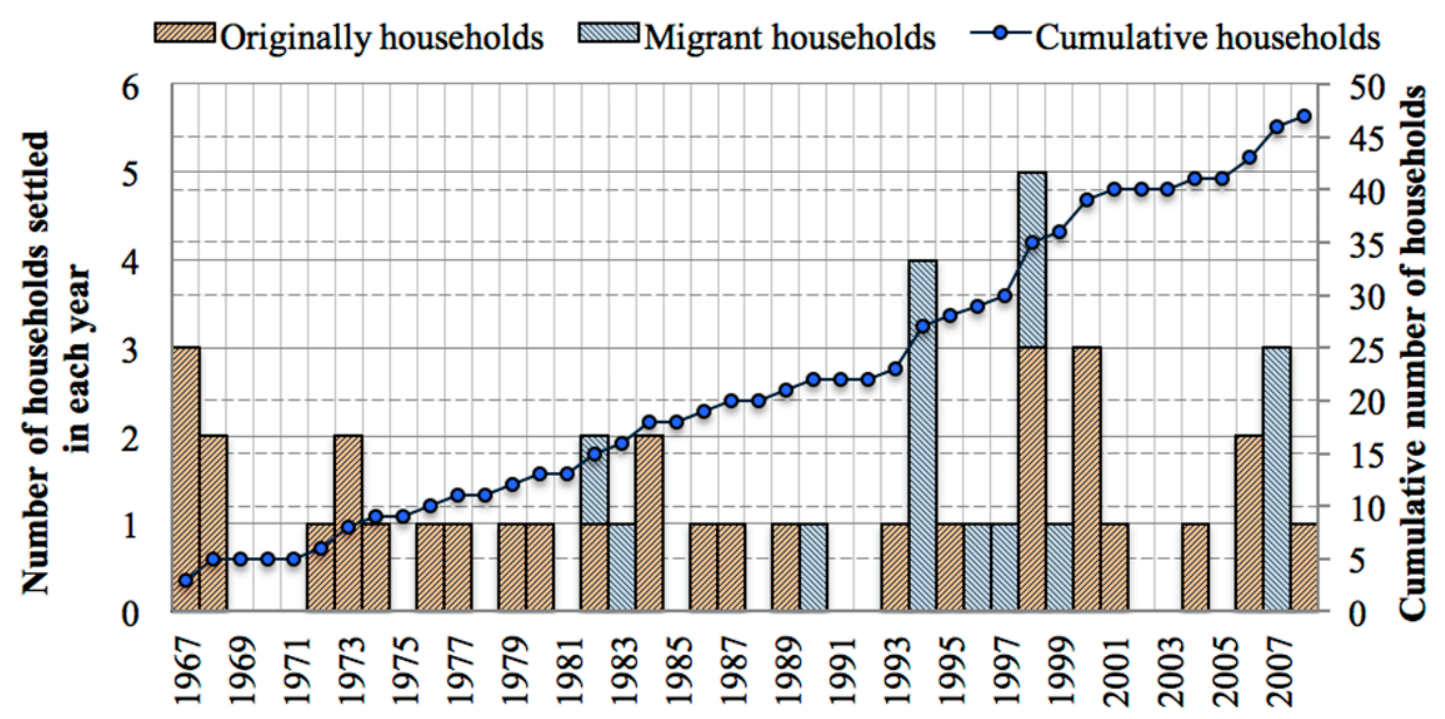

Figure 3. Sample household settlement in the study village.

\subsubsection{Historical Changes of Household Land Tenure}

In this section, we describe how household land tenure has changed over time, based on five major periods defined by activities implemented by government organizations. To facilitate understanding, Figure 4 provides details of changes over time in the ways land use rights were granted to individual households, while Figure 5 shows the transition more intuitively. 
Tenure level

Permanent Land

Use Rights

\begin{tabular}{|c|c|c|c|c|}
\hline & \multicolumn{4}{|r|}{ Use Rights } \\
\hline & \multicolumn{4}{|c|}{ Temporary Land Use Rights } \\
\hline \multicolumn{5}{|c|}{ Customary Land Use Rights } \\
\hline \multicolumn{5}{|c|}{ Leading/ Implemented organization } \\
\hline $\begin{array}{l}\text { Village org. / } \\
\text { Villagers }\end{array}$ & MOF/ DOLHM & $\begin{array}{l}\mathrm{DOF} / \mathrm{DO} \\
\mathrm{DAFO}, \mathrm{NUOL}\end{array}$ & $\begin{array}{l}\text { NAFES/ } \\
\text { PAFO, DAFO }\end{array}$ & $\begin{array}{l}\text { NLMA/ } \\
\text { PLMA, DLMA }\end{array}$ \\
\hline \multicolumn{5}{|l|}{ Initiatives } \\
\hline $\begin{array}{l}\text { Customary } \\
\text { practice }\end{array}$ & $\begin{array}{l}\text { Land Tax } \\
\text { Registration }\end{array}$ & LFA & LUP & $\begin{array}{l}\text { Pilot } \\
\text { LNRA }\end{array}$ \\
\hline $\begin{array}{l}19 \\
\text { Building land } \\
\text { Customary use }\end{array}$ & 993 & 998 & 007 & 2015 \\
\hline $\begin{array}{l}\text { Not registered } \\
\text { yet }\end{array}$ & $\begin{array}{l}\text { Registered as } \\
\text { temporary status }\end{array}$ & \multicolumn{2}{|c|}{$\begin{array}{l}\text { Zoned settlement area surrounding } \\
\text { existing house }\end{array}$} & $\begin{array}{l}\text { Granted Land } \\
\text { Title (bai ta din) }\end{array}$ \\
\hline Paddy field & \multirow{2}{*}{$\begin{array}{l}\text { Some nearby } \\
\text { cropping area } \\
\text { included }\end{array}$} & & & \\
\hline $\begin{array}{l}\text { Some paddy } \\
\text { area expanded }\end{array}$ & & \multicolumn{2}{|c|}{ More paddy area expanded } & \\
\hline $\begin{array}{l}\text { area expanded } \\
\text { Customary use }\end{array}$ & $\begin{array}{l}\text { Most paddy fields } \\
\text { registered }\end{array}$ & $\begin{array}{l}\text { Registered as } \\
\text { temporary status }\end{array}$ & \multirow{2}{*}{$\begin{array}{l}\text { Re-zoned as } \\
\text { "agricultural } \\
\text { land" }\end{array}$} & \multirow{2}{*}{$\begin{array}{l}\text { Renewed and } \\
\text { registered as } \\
\text { TLUC based on } \\
\text { GIS }\end{array}$} \\
\hline $\begin{array}{l}\text { Not registered } \\
\text { yet }\end{array}$ & $\begin{array}{l}\text { Registered with } \\
\text { measurement }\end{array}$ & $\begin{array}{l}\text { Zoned as } \\
\text { "agricultural land" }\end{array}$ & & \\
\hline \multirow{2}{*}{$\begin{array}{l}\text { Upland } \\
\text { agricultural } \\
\text { area }\end{array}$} & \multirow{2}{*}{$\begin{array}{l}\text { Many areas far } \\
\text { from home not } \\
\text { registered }\end{array}$} & & & \\
\hline & & \multirow{2}{*}{$\begin{array}{l}\text { Some claimed } \\
\text { forestland inside } \\
\text { allocated areas as } \\
\text { "agricultural land" }\end{array}$} & & \\
\hline \multirow{2}{*}{$\begin{array}{l}\text { Forestland } \\
\text { converted to } \\
\text { swidden }\end{array}$} & \multirow{2}{*}{$\begin{array}{l}\text { Some shifting } \\
\text { cultivation area } \\
\text { registered }\end{array}$} & & & \\
\hline & & \multirow{3}{*}{$\begin{array}{l}\text { Registered* as } \\
\text { temporary status } \\
\text { Zoned as } \\
\text { "agricultural land" }\end{array}$} & \multirow{3}{*}{$\begin{array}{l}\text { Re-zoned } \\
\text { degraded forest } \\
\text { as "agricultural } \\
\text { land" }\end{array}$} & \multirow{3}{*}{$\begin{array}{l}\text { Renewed and } \\
\text { registered as } \\
\text { TLUC based on } \\
\text { GIS }\end{array}$} \\
\hline Customary use & \multirow{2}{*}{$\begin{array}{l}\text { Registered } \\
\text { without } \\
\text { measurement }\end{array}$} & & & \\
\hline $\begin{array}{l}\text { Not registered } \\
\text { yet }\end{array}$ & & & & \\
\hline \multirow{2}{*}{\multicolumn{2}{|c|}{ Natural forestland }} & $\begin{array}{l}\text { Zoned village } \\
\text { forests }\end{array}$ & $\begin{array}{l}\text { More control all } \\
\text { claimed areas }\end{array}$ & \\
\hline & & \multicolumn{2}{|c|}{$\begin{array}{l}\text { Large part of forest zoned as } \\
\text { "agricultural land" }\end{array}$} & $\begin{array}{l}\text { Household } \\
\text { managed } \\
\text { individual forest }\end{array}$ \\
\hline \multicolumn{3}{|c|}{ Villagers utilized forest products traditionally } & & \\
\hline \multicolumn{3}{|c|}{ Some forestland converted to shifting cultivation } & & Some household \\
\hline \multicolumn{4}{|c|}{ Not registered yet } & granted TLUC \\
\hline
\end{tabular}

Figure 4. Historical changes of household land tenure in the study village. Source: Based on information of consultation meeting with local authorities and group discussion with village organizations. * Based on information in [49]. 


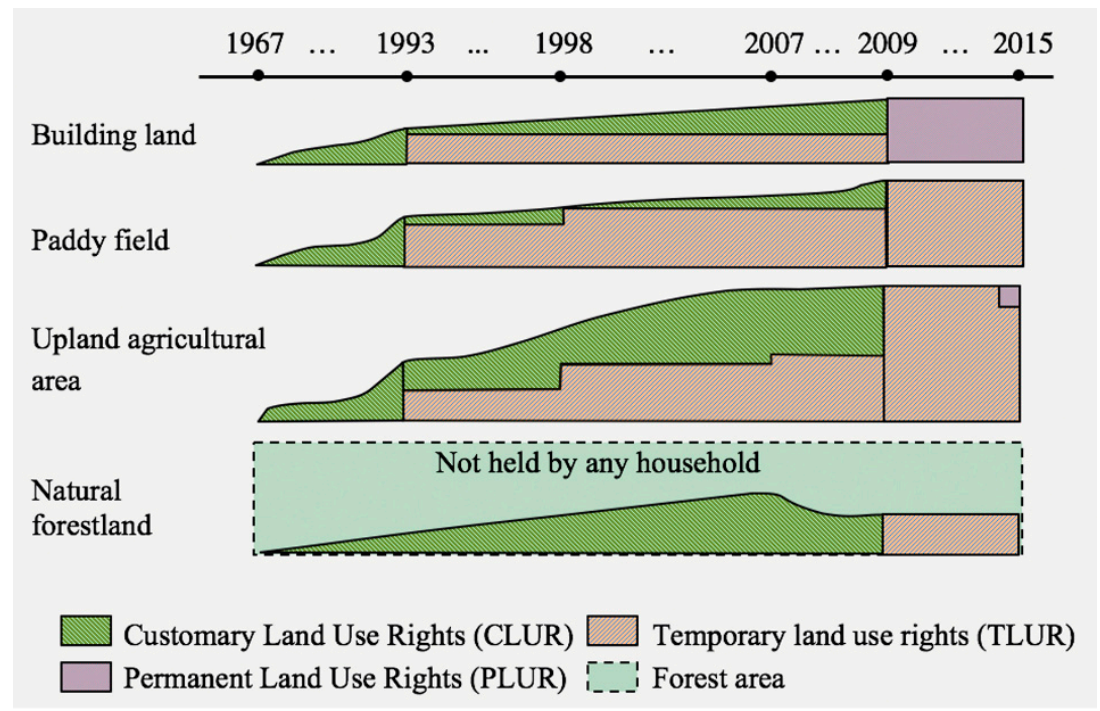

Figure 5. Changes of household land tenure level in the target village.

\section{(1) Customary Practice before 1993}

Before 1993, land in this village was freely accessed and utilized by villagers according to customary practices for uses such as constructing buildings, cultivating paddy fields, conducting upland agriculture, and accessing resources in the forest. Individual households had rights over land commonly understood as CLUR. Utilization of land in this period was based on a first-come, first-served approach (jab jong).

Many households located their housing in the same area near their paddy field. The main agricultural land-use types were rain-fed paddy field (din na), shifting cultivation (din hai), and cropping field (din suan). Lowland areas along streams and valleys were converted to paddy field. Some households established an orchard area in the cropping cultivation field near their paddy field.

Forestland was claimed (jab jong) by many households and utilized mainly as shifting cultivation areas. Selection of the shifting cultivation areas was based on traditional knowledge and local agreement. At this time, land held by households had not been officially registered with the government yet. Forested areas were also freely accessed by villagers for harvesting both timber and NTFPs for subsistence income, and they allowed their cattle to graze on community grasslands near settlements and paddies.

\section{(2) First Land Registration Program in 1993}

In 1993, the first land registration for the land tax system was introduced in villages, under the direction of the Department of Land and House Management Office (DOLHM) (kom tha bien thi din), under the MOF. This registration shifted the tenure status of building land, paddy, and upland agricultural lands from CLUR to TLUR under the TLUC as the official land use rights. The land tax was set out to replace in-kind taxation based on the yield of agricultural products [18]. Land registration documents for tax collection contained information about the landholder, such as area and location, but land mapping was not conducted in the study village. Most of households held TLUR over their land.

Almost all paddy fields were measured in the field and then registered, and some cropping areas surrounding paddy fields were also included in paddy land registration documents. Registration of upland agricultural land, including areas for shifting cultivation, was based on reporting from villagers, without any field survey and measurement; this is because the main target of tax collection was on permanent agricultural land use areas such as paddy fields. Thus, most shifting cultivation areas, including fallow land, were not reported. The natural forestland was not registered for any 
individual household; instead, villagers were allowed to continue utilizing forest resources as a customary practice for their own consumption.

In 1996, the village boundary of Napo was officially demarcated, and a large part of the land area was allocated as state land and established as a model forest for training under the National University of Laos (NUOL) [49].

(3) Land and Forest Allocation Program (LFA) in 1998

In 1998, the LFA was introduced in the study village. The main purpose was to reduce the area of shifting cultivation, promote forest protection, and enhance the livelihoods of the local community. The committee team from the district office (DO), DAFO, and some staff from NUOL carried out the activities at Napo.

A large part of the forestland in this village was zoned for villagers to use as "agricultural land," so paddy fields and areas for cropping, shifting cultivation, fallow land, and raising livestock were all zoned as agricultural land. This included not only land parcels held by villagers both under CLUR and TLUR, but also land not held by anyone under CLUR status.

Moreover, while some land registered as CLUR during the period 1993-1998 had been shifted to TLUR status, some other CLUR land parcels of villagers were not reported and not changed to TLUR. This is because the LFA field survey did not cover all areas inside the agricultural zone, and some villagers were not willing to report the land area that they occupied in the LFA registration progress, because they feared losing land that exceeded the maximum area allowed by law and having to pay the cost of registration, and they wanted to preserve that land for future use [49].

During LFA activities, unoccupied forestland was also allocated to some migrant households and villagers who lacked agricultural land. After the LFA, unoccupied areas inside the agricultural zone (agricultural land) were claimed and expanded by villagers for agricultural cultivation. Villagers were still allowed to continue using forest products—-both timber and NTFPs—as a traditional customary practice for their own consumption.

\section{(4) Land Use Planning in 2007}

In 2007, the National Agriculture and Forest Extension and Service (NAFES) led a program for Land Use Planning (LUP) in Sangthong, especially pilot activities for village land use planning in the study village, and it included others villages in village cluster (koum ban) Five. Due to the fact that, after the LFA in 1998, the area zoned as agricultural land and some parts of the production, protection, and conservation forest in the village were newly claimed by some villagers, and the village organization, with support by the LUP initiative, allocated the lands to individual households (i.e., status changed from CLUR to TLUR) and rezoned it as agricultural land.

While the LUP rezoned agricultural land for individual households, a large part of the land area was zoned as a buffer area; however, this buffer area overlapped with both the household land and land not zoned by the LFA in 1998. To solve this problem, the land was distributed again to individual households. In this process, villagers, including migrant households who lacked agricultural land, were allocated some land parcels for agricultural cultivation, but without TLUR being provided (i.e., status not changed from CLUR to TLUR). Many households got control over jab jong forest area, especially in utilizing forest products inside their fallow land. Villagers could still continue traditional NTFP and timber extraction practices in the village forest areas.

(5) Pilot Land and Natural Resources Registration in 2009

In 2009, a pilot program that had been introduced by the Land and Natural Resources Allocation Project (LNRA) was led by the National Land Management Authority (NLMA), which merged and became MONRE in 2011, Province Land Management Authority (PLMA) (currently PONRE), and the District Land Management Authority (DLMA) (currently DONRE). Land parcels utilized by individual households were registered based on the land information registered in 1993, which consisted of the 
land area being used by households and information from high-resolution satellite images. Registration of agricultural land was based not on field measurements but on geographical information system (GIS) data. All building land (din pouk sang) parcels were systematically titled and granted to individual households, and they obtained PLUR at the highest level of certificate of individual land use rights (bai ta din) of building land. Paddy fields, including new expansion areas, were registered and granted as TLUR. Upland agricultural areas were divided and registered based on land use type, such as cropping field, including the areas registered into paddy documents in 1993; upland rice field including fallow land; and grassland. However, land converted for planting trees (including rubber trees) was not registered independently and included in cropping field or upland rice field. Upland agricultural areas were also granted TLUR.

Preserved natural forestland near households' paddy fields and/or old fallow land was separated from their upland agricultural areas and registered as forestland. About 13 households in the study village were holding forestland as a TLUC. Moreover, most of the households in this village have preserved some forest area as fallow land, including bamboo forest in the same parcels of the upland agricultural area. Those preserved areas have not yet been separated to be registered as forestland or other land use types.

In sum, agricultural land and forestland were granted as TLUR, which could be upgraded to PLUR after three years. In February 2015, according to the vice head of the study village, five parcels of agricultural land were upgraded from TLUR to PLUR status.

As shown in Figure 5, the program granted legal rights over the land to the individual households. CLUR of agricultural land and forestland was shifted to TLUR, which allows the households to utilize and get control over the land, including managing natural resources inside their land, such as timber, fuel wood, and bamboo, and/or renting out the land to other households. Both CLUR and TLUR over building land were shifted to PLUR.

\subsubsection{How Households Obtained Land Use Rights}

\section{(1) Acquisition of Paddy Field and Upland Agricultural Areas}

Figures 6 and 7 show the majority of households obtained agricultural land through the claim process, particularly in the upland agricultural area. Sample households also obtained agricultural land through inheritance and transfer processes over time. Inheritance of agricultural land shifted landholdings among household members and relatives.

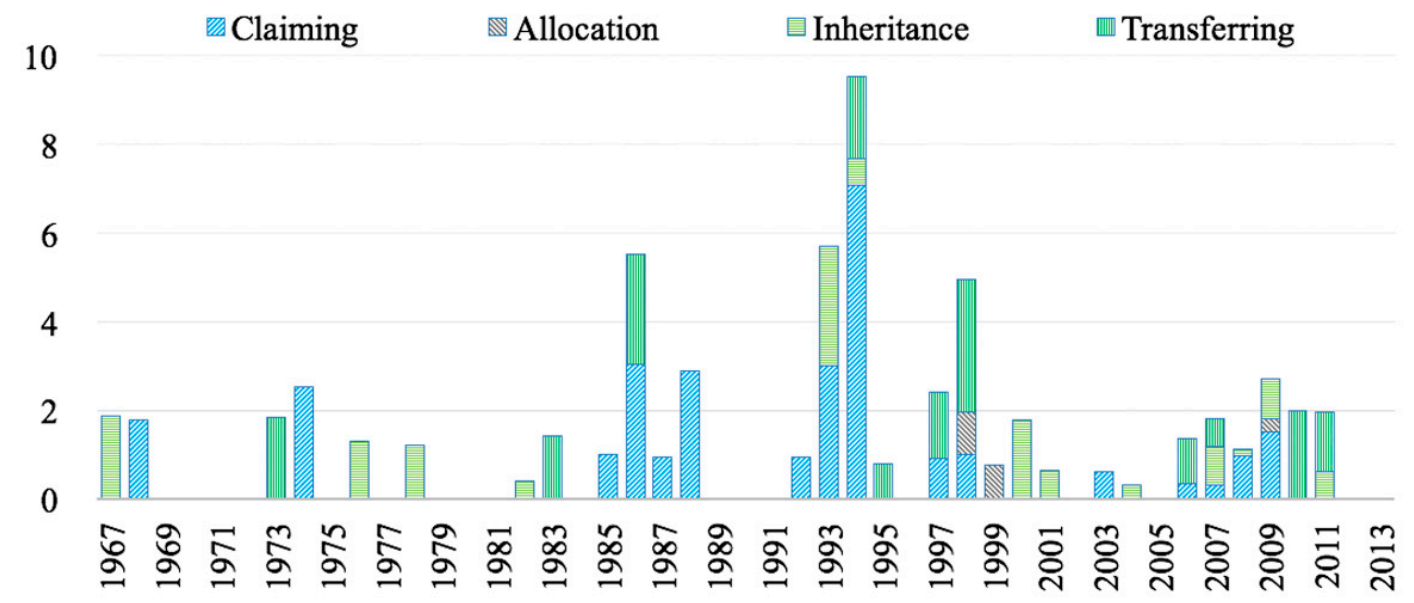

Figure 6. Sample households that obtained paddy fields. Source: Household survey. 


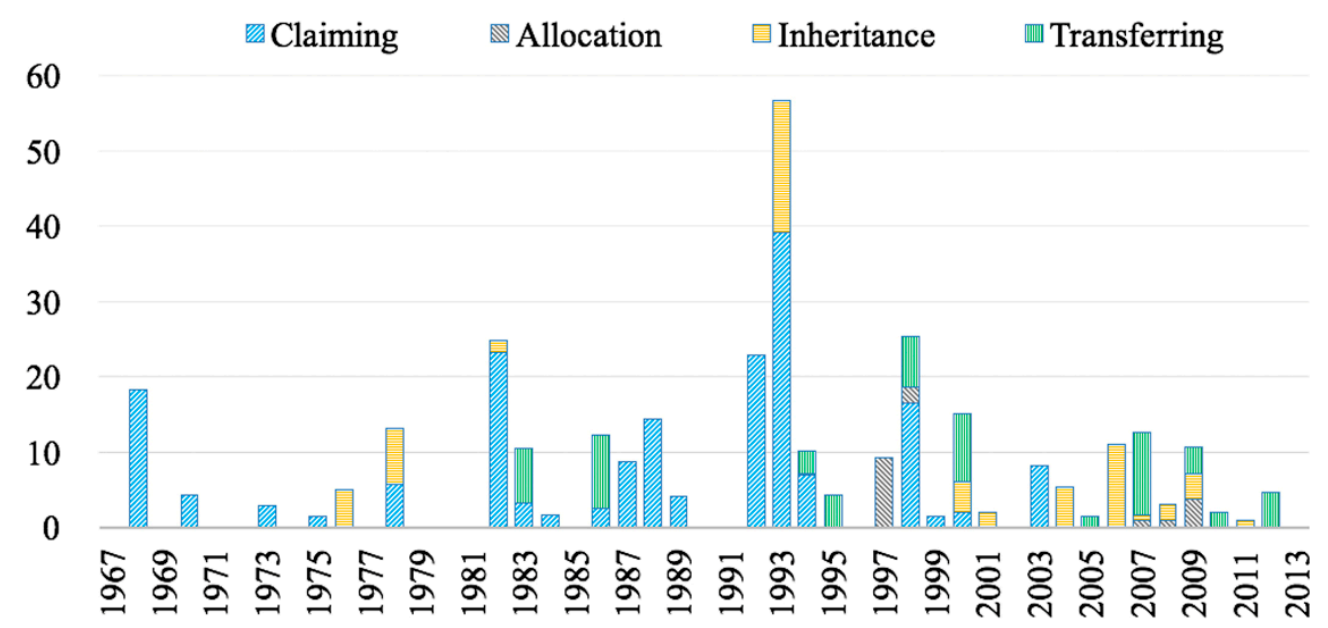

Figure 7. Sample households that obtained upland agricultural land. Source: Household survey.

(2) Agricultural Area and Forestland within Groups of Households

Figure 8 compares the average area of agricultural land obtained by the sample households between original and migrant households in three periods: before 1993, from 1993 to 2008, and from 2009 to 2013. The average of claimed agricultural area, both paddy and upland agricultural, obtained by the original households is larger than the area claimed by migrant households. Conversely, the average agricultural land area held by migrant households through a transfer process is larger than the area obtained by the original households. Meanwhile, there are differences in the ways original households and migrant households obtained their land. Original households had the opportunity to occupy a large area and claimed the land use rights there. Only a small area was left for migrant households to be claimed. They mainly obtained agricultural land through a transfer process.

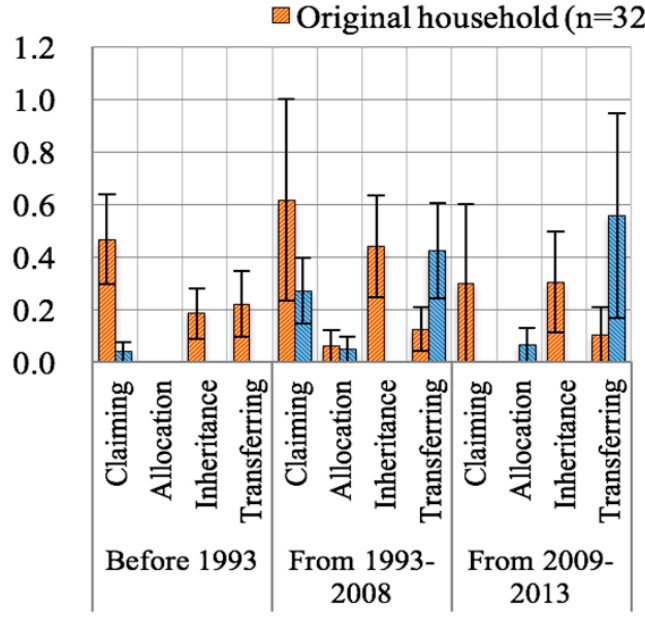

(a)

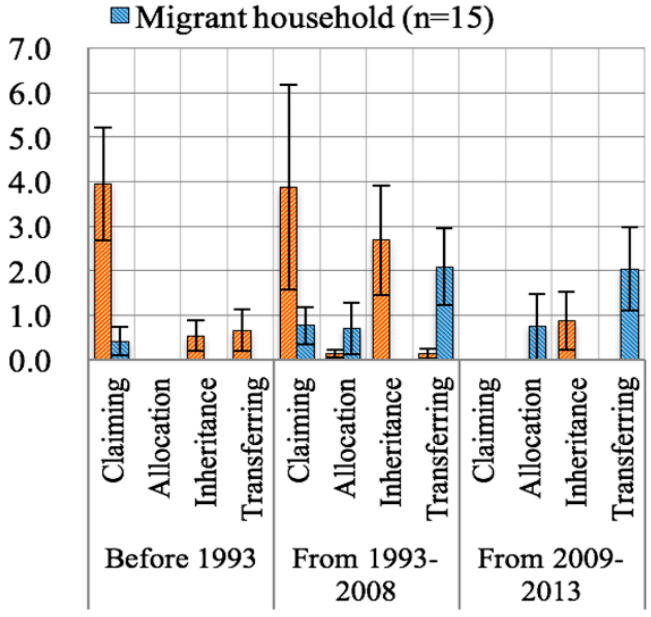

(b)

Figure 8. (a) Average paddy area obtained by sample households; (b) Average upland agricultural area obtained by sample households (Units: hectares per household).

Regarding natural forestland, only three households in each group obtained forestland through the claim process. Initially, households claimed forest area for agricultural cultivation. After that, some land was divided from the agricultural land and kept as fallow land, and some households reserved forest area near their paddy or other agricultural land for harvesting forest products (NTFPs and timber), and thus were easier to access than other village or state forest areas. When the land registration program was introduced in 2009 , some villagers proposed to separate those areas from 
the agricultural land and then registered them as forestland. Other households kept the land fallow, but converted it back to agricultural land because they feared losing it to the government.

\section{(3) Changes of Landholders from Villagers to Outsiders}

Recently, land transfers have taken place not only among villagers in the same village, as some upland agricultural land has also been transferred to persons living outside this village. During the years 2007 to 2013, nearly 50 hectares of upland agricultural areas were transferred to outsiders. Some local businessmen showed an interest in holding large areas of agricultural land for development for investment activities, such as livestock farming and a white charcoal factory. Moreover, villagers may have needed more cash for buying tractors and house-building materials, and some households sold land because of a family member's accident, illness, or death. The land price is also increasing, and some households are planning to sell more of their upland agricultural areas.

\section{Discussion}

\subsection{Safeguarding and Shifting of Land Tenure and Land Use Rights}

Shifting of land use rights from CLUR to TLUR and TLUR to PLUR has provided an opportunity for households to obtain a higher level of land use rights. These changes have increased the security level of households' land holdings by shifting the informal and customary basis of holding land use rights to a legal basis. Increasing the status of household land use rights may have provided not only an opportunity to safeguarding their rights, but also to increase the economic value of the land, and more opportunity to access credit and the land market on a formal basis, particularly through land use rights at the PLUR level. If a development or concession project is introduced in the area, landholders now have a better chance of receiving fair compensation. Their land cannot be taken away by investors with little or no compensation, in contrast to what has happened in many concession areas [50,51].

Land formalization programs have also provided opportunities for individual households to change land use types. Shifting from CLUR to TLUR resulted in land use shifting from forestland to agricultural land, triggered by registration and allocation activities. Forestland decreased when land use rights went from CLUR to TLUR.

The literature reviewed for this study (see Section 3.1.2), confirmed that in our study village households' land occupation is a threat to the community and village land. Individual households claimed not only available land parcels (land not claimed by any other household) under the LFA zoned as "agricultural land," but also areas within community land and village land for agricultural cultivation. The area of village land has decreased, as it did in the agricultural commercialization area $[33,52]$. Some villagers did not follow the LFA process or the poorly implemented LFA program [39]. Such land occupation would not normally be accepted by the village authorities in the registration process. Even in the case of acceptance, the transfer of those land parcels to another household or to outsiders would normally not be allowed. Otherwise, it would create the risk of other land parcels of the community and state land being occupied.

Most households are holding expired of the TLUC. In order to secure more land use rights for local villagers, upgrading from TLUR to PLUR status should continue. However, the upgrading progress still needs more effort and may take more time, because the titling of land needs to be conducted through new field surveys to re-measure the area. The previous surveying and measuring information is likely insufficient and unusable.

Furthermore, land transfers using CLUR and TLUR status are now considered illegal. Informal land transfers to outsiders have likely increased in the upland area, because road accessibility to the village is now more convenient. Informal land transfers could put more local villagers at risk in holding land, and could provide an opportunity for outsiders to purchase or grab more land. Informal transfer processes could be turned into a formal process by buyers offering a commission to local staff, who may have already received some bribes and provided services for land registration [30]. Meanwhile, 
at the time of purchase, the land is sold under a TLUR condition. After the transferring process is completed, a new landholder could obtain the land parcels under the PLUR status. Thus, the buyers take advantage of land transfer, and they may capture the long-term benefit through the process [53].

\subsection{Land and Forest Formalization and the Changing of Land Tenure}

In our study, village, the LFA stimulated some households to occupy or claim more land that the LFA had zoned as agricultural land. The claim process could be continued until no more land was available to be claimed or no-one could get any more upland area through the claim process in the zoning area. This claim practice could be influenced in occupying more on other community land/village land or even state land. Meanwhile, if land is not zoned and registered properly, more community land could be besieged by claims in the near future. Thus, community or village land is still under threat.

In our study, village, land registration in 2009 separated claimed forest areas, including old fallow land, from household agricultural land and then granted a TLUC as forestland. The granting of TLUR over forestland to village households can have both positive and negative effects. The positive effects could be (1) more forest area protected and conserved by households; (2) opportunity to reduce the area of deforestation if land is managed effectively; and (3) increased rights and sense of responsibility for households to manage land; and (4) provision of exclusive control to households for managing forests in the granted land area. Conversely, negative effects could be (1) households' loss of interest in protecting community or state forest area [11]; (2) the households manage the individual forest areas in a way that may not follow their villages' regulations, but freely create their own rules, which could lead to further conflict in harvesting forest products; and (3) possible conflicts between rights over land versus forest resources, especially where this involves the harvesting of big trees or timber with high commercial value (such as rosewood) on those lands.

\subsection{Inequality in Obtaining Land Use Rights among Individual Households}

With regard to equity issues, fairness in redistribution of resources means improving the equity of property rights [54]. The land formalization and allocation program Laos' has not always been seen as fair. LTP formalization activities are focused on access to land registration [7] rather than equity in distribution of land per individual or per household. Moreover, the purpose of LFA is mainly to increase state control over both communities' and villagers' land, rather than allocating ownership rights to local villagers and communities.

In the study village, we found that the original households had claimed larger areas of agricultural land than the migrant households. Whether or not those agricultural areas were informally or customarily claimed, all claims were triggered by the registration program. Furthermore, recognizing and acknowledging the previous intervention activities of the households, the claiming of land was a significant cause of imbalances in the granting of land use rights to individual households. Meanwhile, the claiming of land by households was a factor in inequality. Original households took advantage of the land registration process, likely unfair to migrant households, because the original households were granted land use rights over large areas that they claimed.

On the other hand, agricultural land was informally and customarily transferred between individual households. Due to the fact that most of the agricultural land in the zoned areas was claimed by the original households, the chance for migrant households to claim land was limited. Since land area allocated by the local authorities was not large enough for shifting cultivation, migrant households have had to purchase more agricultural land in both paddy and upland agricultural areas to secure their livelihoods. Meanwhile, many agricultural land use parcels were shifted from the original households to migrant households through the transfer process. Thus, migrant households had to invest more capital to improve their household economy, especially with the high cost of purchasing land, and this transaction cost is higher than the money invested in agricultural cultivation 
activities. In turn, they get more opportunity to turn land into capital and may still have enough land for agricultural cultivation.

From a policy perspective, equity is an important issue in land governance. The new form of land governance involves "social exclusion, inequity and ecological simplification" [55]. Since land registration in Laos is incomplete, and there is a limited of data set [40], the fairness of land distribution through the registration system may not be predictable.

Land granted for investment and development projects is also a key factor that has had an impact on changes to the land use rights of the local community, especially land allocated for large-scale land concessions, which could affect local households' livelihoods and land use rights [51]. Most villagers already face challenges with livelihoods and farming. The livelihoods of some local farmers have changed, for instance, from being farmers to wage laborers for plantation companies or becoming migrants in a neighboring country $[15,20,22,50,56,57]$. These problems are also important, although beyond the scope of this study. A future study may explore changes in community land tenure and land use rights where villagers share their land through contract farming systems " $2+3$ " or events " $1+4$ " forms $[44,58]$ or villagers renting out their land to investors through local land brokers or middle men, especially banana farming in the northern part of Laos [59], as well as the direct impacts of the changing of land use rights by concession projects.

Moreover, institutional arrangements could be an underlying cause of the changing of the households in holding land use rights. A future study might examine how land use rights have been affected by institutional reforms and decentralization in Laos.

\section{Conclusions}

An understanding of government land formalization programs and historical changes in the ways land use rights have been attributed to individual households is essential for future land governance and tenure reforms in Laos. This is especially true for the allocation of land for rural households. Our study described consequences of the changes from "customary land use rights" (CLUR) to "temporary land use rights" (TLUR) and "permanent land use rights" (PLUR) in a selected local community, after the government started implementing a series of land formalization programs in the 1990s.

In the study village of Napo, land formalization programs shifted individual households' land use rights from CLUR to TLUR and then to the PLUR level, but imbalances were created in the process. Original households that were present longer in the community (in 1980 or earlier) were more likely to take advantage from these transformation processes, particularly by claiming land, whereas migrant households (arriving after 1980) lacked the opportunity to claim land for their use. They mostly obtained their land through a transfer process, by investing more of their financial capital to purchase land.

This study has important implications for the Laos government in assisting rural communities with land use rights, increasing their tenure level, and enhancing the safeguarding of land use rights of local villagers. Land titling should not focus only on cities, but should also continue in rural areas. Conditions that lead to households having expired temporary land use certificates (TLUCs) tend to be unfair for rural households. Systems should be put in place so that they can hold their land use rights, with protections similar to the rights obtained by city dwellers. The risks of rural households losing land use rights may be decreased if formalization programs are carried out properly and premised on a respect for customary land use rights, providing opportunities for poor rural households to manage their land formally. Land tenure reforms should be implemented in an equitable manner on community land and state land.

This case study showed that the current land-titling program does not always result in farming households experiencing improvement in their livelihoods and economic conditions, but may exaggerate inequality in accessing land. Such outcomes may be a reflection of the government's sometimes conflicting policy objectives between LTP and LFA. Further analysis of policy overlap 
could reveal more nuances and insights into the complexities of land issues in Laos, not only from the perspective of community and individual household rights to use and own the land, but also from the perspective of the politics of policy.

In conclusion, this study showed some of the risks and opportunities faced by rural households and communities in government-directed processes to formalize land tenure and rights, and suggested ways governments can produce more equitable outcomes as they extend land-titling processes in the rural areas of Laos.

Supplementary Materials: The Supplementary Materials are available online at http:/ / www.mdpi.com/2073-445X/5/2/11/s1.

Acknowledgments: The research presented in this paper was conducted through the collaborative project "Action Research on Community Forest Carbon Accounting," led by the Faculty of Forestry Sciences, National University of Laos (NUOL) and the Institute for Global Environmental Strategies (IGES). The authors would like to thank the following staff from NUOL for their help during the fieldwork: Vongphet Syhapanya, Phokeo Kounnavong, and Bounsong Sorthanongxay. We also would like to thank all villagers interviewed and district staff for their willingness to share information. Special thanks to Randy Helten for useful comments and proofreading. We are grateful to two reviewers for their helpful comments and suggestions on an earlier version of this manuscript.

Author Contributions: Saykham Boutthavong carried out the field survey and data collection with the help of Kimihiko Hyakumura. Saykham Boutthavong analyzed the data and interpreted the results with the help of Makoto Ehara and Kimihiko Hyakumura. Takahiro Fujiwara contributed to the introduction and conclusion. Saykham Boutthavong was the principal writer.

Conflicts of Interest: The authors declare no conflict of interest.

\section{References and Notes}

1. Yasmi, Y.; Kelley, L.; Enters, T. Conflict over Forests and Land in Asia: Impacts, Causes, and Management; RECOFTC: Bangkok, Thailand, 2010.

2. Holstein, L. Towards Best Practice from World Bank Experience in Land Titling and Registration. 1996. Available online: https:/ /www.rmportal.net/framelib/ltpr/052709/holstein-wb-best-practices-titling.pdf (accessed on 4 September 2015).

3. Hall, D.; Hirsch, P. Land titling in Southeast Asia: Debates and conundrums. In Proceedings of the Conference on Revisiting Agrarian Transformations in Southeast Asia: Empirical, Theoretical and Applied Perspectives, Chiang Mai, Thailand, 13-15 May 2010.

4. Hall, D.; Hirscb, P.; Li, T.M. Introduction to Powers of Exclusion: Land Dilemmas in Southeast Asia; National University of Singapore Press: Singapore, 2011.

5. Corbera, E. Powers of exclusion. Land dilemmas in Southeast Asia. J. Peasant Stud. 2012, 39, $221-225$. [CrossRef]

6. Lastarria-Cornhiel, S. Who Benefits from Land Titling? Lessons from Bolivia and Laos; International Institute for Environment and Development (IIED): London, UK, 2007.

7. Dixon, R.; Lunnay, C. Lao Land Titling Project: Implementation and Lessons; Unpublished work, 2009.

8. Ducourtieux, O.; Castella, J. Land reforms and impact on land use in the uplands of Vietnam and Laos: Environmental protection or poverty alleviation? In Proceedings of the Colloque International “Les Frontières de la Question Foncière - At the Frontier of Land Issues", Montpellier, France, 17-19 May 2006.

9. Soulivanh, B.; Chanthalasy, A.; Suphida, P.; Lintzmeyer, F. Study on Land Allocation to Individual Households in Rural Areas of Lao PDR; German Technical Cooperation: Vientiane, Lao PDR, 2004.

10. Fujita, Y.; Phengsopha, K.; Vongvisouk, T.; Thongmanivong, S. Post-socialist land reform in Lao PDR and its impact on community land and social equity. In Proceedings of the Eleventh Conference of the International Association for the Study of Common Property (IASCP), Bali, Indonesia, 19-23 June 2006.

11. Vandergeest, P. Land to some tillers: Development-induced displacement in Laos. Int. Soc. Sci. J. 2003, 55, 47-56. [CrossRef]

12. USIAD. Lao People's Democratic Republic (Lao PDR)—Property Rights and Resource Governance Profile. 2013. Available online: http://www.usaidlandtenure.net/sites/default/files/country-profiles/ full-reports/USAID_Land_Tenure_Laos_Profile.pdf (accessed on 16 January 2015). 
13. Mann, E.; Luangkhot, N. Study on Women's Land and Property Rights Under Customary or Traditional Tenure Systems in Five Ethnic Groups of Lao PDR; Land Policy Study No. 13 under LLTP II; Lao-German Land Policy Development Project: Vientiane, Lao PDR, 2008.

14. LIWG. Key Recommendations for the Lao National Land Policy; Land Issues Working Group (LIWG): Vientiane, Lao PDR, 2014.

15. Dwyer, M.B. Trying to Follow the Money: Possibilities and Limits of Investor Transparency in Southeast Asia's Rush for "Available" Land; CIFOR: Bogor, Indonesia, 2015.

16. Dwyer, M.B.; Ingalls, M. REDD + at the Crossroads: Choices and Tradeoffs for 2015-2020 in Laos; CIFOR: Bogor, Indonesia, 2015.

17. PROFEP. Management Plan for Forest Resources Development, Training and Research in the Management Intervention Area of Sangthong District, Vientiane Municipality 2001-2010; Promotion of Forestry Education Project (PROFEP), Faculty of Forestry, National University of Laos: Vientiane, Lao PDR, 2000.

18. Kirk, M. Land Tenure Development and Divestiture in Lao P.D.R; Deutsche Gesellschaft für Technical Zusammenarbeit (GTZ): Vientiane, Lao PDR, 1996.

19. Hirsch, P.; Scurrah, N. The political economy of land governance in the Mekong Region: Contexts of policy advocacy. In Proceedings of the International Academic Conference on Land Grabbing, Conflict and Agrarian-Environmental Transformations: Perspectives from East and Southeast Asia, Chiang Mai University, Chiang Mai, Thailand, 5-6 June 2015; Conference Paper No. 48.

20. Baird, I.G. Turning land into capital, turning people into labor: Primitive accumulation and the arrival of large-scale economic land concessions in the Lao People's Democratic Republic. New Propos. J. Marx. Interdiscip. Inq. 2011, 5, 10-26.

21. Kenney-Lazar, M. Authoritarian resource governance and emerging peasant resistance in the context of Sino-Vietnamese Tree Plantations, Southeastern Laos. In Proceedings of the International Academic Conference on Land Grabbing, Conflict and Agrarian-Environmental Transformations: Perspectives from East and Southeast Asia, Chiang Mai University, Chiang Mai, Thailand, 5-6 June 2015; Conference Paper No. 2.

22. Hett, C.; Nanhthavong, V.; Saphangthong, T.; Robles, G.R.; Phouangphet, K.; Epprecht, M.; Heimimann, A.; Messerli, P. Land deals in Laos: First insights from a new nationwide initiative to assess the quality of investments in land. In Proceedings of the International Academic Conference on Land Grabbing, Conflict and Agrarian-Environmental Transformations: Perspectives from East and Southeast Asia, Chiang Mai University, Chiang Mai, Thailand, 5-6 June 2015; Conference Paper No. 18.

23. Virachit, V.; Lunnay, C. The lao land titling project-Innovative land tools in Lao PDR. In Proceedings of the Expert Group Meeting on Secure Land Tenure: “New Legal Frameworks and Tools" (UNESCAP), Bangkok, Thailand, 8-9 December 2005; pp. 1-13.

24. Rusanen, L. In Whose Interests?: The Politics of Land Titling; Background Paper; AID/Watch: Sydney, Australia, 2005.

25. Land Law; National Assembly: Vientiane, Lao PDR, 2003.

26. Prime Minister's Office. Decree on the Implementation of the Land Law; Prime Minister's Office: Vientiane, Lao PDR, 2008.

27. Burapha Development Consultants. Final Report of the Social Assessment for the Six Served Provinces and Two Unserved Provinces of the Lao PDR Land Titling Project; Burapha Development Consultants: Vientiane, Lao PDR, 2003.

28. Government of Laos. Five Year National Socio-Economic Development Plan VIII (2016-2020); Government of Laos: Vientiane, Lao PDR, 2015.

29. Vaenkeo, S. Land title issuance accelerated but target won't be met. Vientiane Times, 15 June 2015.

30. Vaenkeo, S. Govt set to issue 60,000 land titles next fiscal year. Vientiane Times, 17 September 2015.

31. Vaenkeo, S. Ministry reaffirms plan to issue 400,000 land titles by 2020. Vientiane Times, 15 October 2015.

32. Fujita, Y.; Phanvilay, K. Land and forest allocation in Lao People's Democratic Republic: Comparison of case studies from community-based natural resource management research. Soc. Nat. Resour. 2008, 21, 120-133. [CrossRef]

33. Manivong, K.; Sophathilath, P. Land Use Planning and Land Allocation in the Upland of Northern Laos: Process Evaluation and Impacts; The Economy and Environment Program for Southeast Asia (EEPSEA): Singapore, 2009. 
34. National Agriculture and Forestry Research Institute (NAFRI). Research Report on The Effect of Village Re-Location on Previous Land Allocation in Phonexay, Luang Prabang and Namo, Oudomxay; Lao Swedish Upland Agriculture and Forestry Research Program (LSUAFRP), NAFRI: Vientiane, Lao PDR, 2007.

35. Moizo, B. Implementation of the land allocation policy in the Lao PDR: Origins, problems, adjustments and local alternatives. In Proceedings of the Workshop on Poverty Reduction and Shifting Cultivation Stabilisation in the Uplands of Lao PDR: Technologies, Approaches and Methods for Improving Upland Livelihoods, Luang Prabang, Lao PDR, 27-30 January 2004; pp. 103-116.

36. Lestrelin, G.; Bourgoin, J.; Bouahom, B.; Castella, J.C. Measuring participation: Case studies on village land use planning in northern Lao PDR. Appl. Geogr. 2011, 31, 950-958. [CrossRef]

37. Naughton-Treves, L.; Day, C. Lessons about Land Tenure, Forest Governance and REDD+Case Studies from Africa, Asia and Latin America; UW-Madison Land Tenure Center: Madison, WI, USA, 2012.

38. Phengkhay, C. Women and Land Allocation in Lao PDR. Master's Thesis, Asian Institute of Technology, Bankok, Thailand, 1999.

39. Ducourtieux, O.; Laffort, J.R.; Sacklokham, S. Land policy and farming practices in Laos. Dev. Change 2005, 36, 499-526. [CrossRef]

40. Scurrah, N.; Hirsch, P. The Political Economy of Land Governance in Lao PDR; Sisattanak District: Vientiane, Lao PDR, 2015.

41. Dwyer, M. Turning Land into Capital: A Review of Recent Research on Land Concessions for Investment in Lao PDR; Land Issues Working Group: Vientiane, Lao PDR, 2007.

42. NA. Constitution of the Lao People's Democratic Republic; National Assembly: Vientiane, Lao PDR, 2003.

43. Chokkalingam, U.; Phanvilay, K. Forest Governance Assessment for REDD+ Implementation in Lao PDR through Application of the PROFOR Forest Governance Tool; Forest Carbon Partnership Facility (FCPF): Washington, DC, USA, 2014.

44. Danielle, T. Trends in Southeast Asia. Chinese Engagement in Laos: Past, Present, and Uncertain Future; ISEAS: Singapore, 2015.

45. Baird, I.G. Political memories of conflict, economic land concessions, and political landscapes in the Lao People's Democratic Republic. Geoforum 2014, 52, 61-69. [CrossRef]

46. Baird, I.G.; Le Billon, P. Landscapes of political memories: War legacies and land negotiations in Laos. Polit. Geogr. 2012, 31, 290-300. [CrossRef]

47. Suhardiman, D.; Giordan, M.; Keovilignavong, O.; Sotoukee, T. Revealing the hidden effect of land grabbing through better understanding of farmers' strategies in dealing with land loss. Land Use Policy 2015, 49, 195-202. [CrossRef]

48. Guttal, S.; Manahan, M.A.; Militante, C.; Morrissey, M. Keeping Land Local: Reclaiming Governance from the Market Land; LRAN and Focus on the Global South: Bangkok, Thailand, 2014.

49. Funke, I.E. Analysis of Land Allocation and Implications on Land Management: A Case Study of Two Villages in Sang Thong District, Vientiane Municipality, Lao PDR. Master's Thesis, Dresden University of Technology, Tharandt, Germany, 2001.

50. Kenney-Lazar, M. Plantation rubber, land grabbing and social-property transformation in southern Laos. J. Peasant Stud. 2012, 39, 1017-1037. [CrossRef]

51. De Schutter, O. How not to think of land-grabbing: three critiques of large-scale investments in farmland. J. Peasant Stud. 2011, 38, 249-279. [CrossRef]

52. Thongmanivong, S.; Fujita, Y. Recent land use and livelihood transitions in Northern Laos. Mt. Res. Dev. 2006, 26, 237-244. [CrossRef]

53. Schlager, E.; Elinor, O. Property-rights regimes and natural resources: A conceptual analysis. Land Econ. 1992, 68, 249-262. [CrossRef]

54. Meinzen-Dick, R.S.; Brown, L.R.; Feldstein, H.S.; Quisumbing, A.R. Gender, property rights, and natural resources. World Dev. 1997, 25, 1303-1315. [CrossRef]

55. Sikor, T.; Auld, G.; Bebbington, A.J.; Benjaminsen, T.A.; Gentry, B.S.; Hunsberger, C.; Izac, A.M.; Margulis, M.E.; Plieninger, T.; Schroeder, H.; et al. Global land governance: From territory to flow? Curr. Opin. Environ. Sustain. 2013, 5, 522-527. [CrossRef]

56. Barney, K. Power, Progress and Impoverishment: Plantations, Hydropower, Ecological Change and Community Transformation in Hinboun District, Lao PDR; York Centre for Asian Research (YCAR), York University: Toronto, ON, Canada, 2007. 
57. Baird, I.; Fox, J. How land concessions affect places elsewhere: Telecoupling, political ecology, and large-scale plantations in Southern Laos and Northeastern Cambodia. Land 2015, 4, 436-453. [CrossRef]

58. Baird, I.G. Land, rubber and people: Rapid agrarian changes and responses in Southern Laos. J. Lao Stud. 2009, 1, 1-47.

59. Friis, C. Small-scale land acquisitions, large-scale implications: The case of Chinese banana investments in Northern Laos. In Proceedings of the International Academic Conference on Land Grabbing, Conflict and Agrarian-Environmental Transformations: Perspectives from East and Southeast Asia, Chiang Mai University, Chiang Mai, Thailand, 5-6 June 2015; Conference Paper No. 36.

(C) 2016 by the authors; licensee MDPI, Basel, Switzerland. This article is an open access article distributed under the terms and conditions of the Creative Commons Attribution (CC-BY) license (http://creativecommons.org/licenses/by/4.0/). 